\title{
Dietary effects of n-6:n-3 polyunsaturated fatty acid ratios on the antioxidant status of the liver in goslings $^{*}$
}

\author{
M.Z. Wang'1 , L.Y. Ding, J.F. Wang, L.H. Yu and H.R. Wang \\ College of Animal Science and Technology, Yangzhou University \\ Yangzhou, Jiangsu province, 225009, P.R. China
}

(Received 22 March 2012; revised version 8 May 2012; accepted 19 June 2012 )

\begin{abstract}
The objective of this study was to investigate the effects of dietary n-6:n-3 polyunsaturated fatty acid (PUFA) ratios on the oxidative stress of the liver in goslings. A total of 160 healthy Yangzhou geese was randomly divided into 4 groups, and each group was fed on diets with different n-6:n-3 PUFA ratios: A (12:1), B (9:1), C (6:1), and D (3:1), respectively. The liver was separated and antioxidant functions were evaluated on days 42,56 , and 70 . The results showed that the activities of total superoxide dismutase, glutathione peroxidase, and catalase decreased when the geese aged, and were highest on $\mathrm{d} 42$ in each group $(\mathrm{P}<0.05)$. The activities of these enzymes increased as the n-6:n-3 PUFA ratios decreased and were highest in the 3:1 group at all tested ages $(\mathrm{P}<0.05)$. It was also observed that the levels of $\mathrm{H}_{2} \mathrm{O}_{2}$, malondialdehyde (MDA), and nitric oxide (NO) in liver tissue tended to increase with age, and were relatively higher on $\mathrm{d}$ 70. Furthermore, the levels of $\mathrm{H}_{2} \mathrm{O}_{2}$, MDA, and NO decreased as n-6:n-3 PUFA ratios decreased and were lowest at 3:1 and 6:1 at all studied ages $(\mathrm{P}<0.05)$. Overall, diets containing comparatively low $n-6: n-3$ PUFA ratios, such as 3:1 or 6:1, could increase antioxidant function and decrease hepatocyte damage in liver tissue.
\end{abstract}

KEY WORDS: n-6:n-3 polyunsaturated fatty acid, liver, oxidative stress, goslings

\footnotetext{
* Supported by the NSFC of China, Grant No. 31072051, and the Natural Science Foundation of Jiangsu province, Grant No. SBK201121885, P.R. China

${ }^{1}$ Corresponding author: e-mail: mengzhiwang@yahoo.cn or mzwang@yzu.edu.cn
} 


\section{INTRODUCTION}

Oxidative stress and damage to biomolecules by free radicals have been linked to aging and a variety of chronic diseases, particularly cardiovascular disease and cancer. As modern society develops, antioxidation, anti-aging, and suboptimal health are drawing increasingly more attention (Eder et al., 2002; Crane et al., 2005). Research (Liu, 2009) has suggested that polyunsaturated fatty acids (PUFA) can scavenge free radicals, improve the activities of superoxide dismutase (SOD) and other antioxidant enzymes, and may exert a preventive antioxidant role against free radical action. Animals can not covert n-6 PUFA into n-3 PUFA or vice versa and these two classes of fatty acids are competitive with each other in metabolic processes. The appropriate ratio of n-6:n-3 PUFA in diets is deemed to be essential for increasing antioxidant and anti-stress capacity and maintaining health status. To date, however, a reasonable range of n-6:n-3 PUFA ratios has not been clearly established; moreover, there are very few publications focusing on the ratios impacting the antioxidation functions of vital organs such as liver (Wang et al., 2009).

The Yangzhou goose is a major breed in China, and was approved as the first national goose breed by the National Examination and Approval Committee of Domestic Animal and Poultry Breeds in 2006. Research on Yangzhou goose has mainly been concentrated on growth performance, nutritional requirements, gastrointestinal tract morphology, etc. (Shi et al., 2007; Wang et al., 2008, 2010; Liu et al., 2010). The effects of n-6:n-3 PUFA ratios on liver oxidation susceptibility in this breed have not been reported up to now. The hypothesis of the present study was that dietary n-6:n-3 PUFA ratios are associated with liver antioxidant function in geese. Thus, the Yangzhou goose was taken as the experimental bird in this study aimed at assessing the effects of n-6:n-3 PUFA ratios on liver oxidation resistance by feeding diets with different $n-6: n-3$ PUFA ratios, and also at providing some references for the scientific utilization of oil feeds.

\section{MATERIAL AND METHODS}

\section{Experimental birds and feeding}

The feeding experiment was conducted from November 2009 to March 2010, at the experimental farm of Yangzhou University (Yangzhou, Jiangsu Province, P.R. China). All animal handing protocols were approved by the Yangzhou University Animal Care and Use Committee. A total of 160 healthy Yangzhou geese ( 80 male and 80 female) with a similar weight 
$(0.407 \pm 0.023 \mathrm{~kg})$, aged 21 days, were randomly divided into 4 groups. Each group contained 4 replications, 10 birds each in a block ( 5 male and 5 female). Each group of birds was randomly allocated to one of four diets (n-6:n-3 PUFA ratios were 12:1, 9:1, 6:1, and 3:1, respectively) shown in Table 1. A maize-peanut meal basal diet was designed referring to NRC (1994) and other studies on this breed. Palmitic and oleic acids were purchased from Zibo Wanyou Chemical Co. Shandong Province (China), and the purity of palmitic and oleic acids were 99.9 and $99.8 \%$, respectively. The birds were fed with $1 / 3$ original diet $+2 / 3$ experimental diet for 2 days, $1 / 2$ original diet $+1 / 2$ experimental diet for 2 days, $2 / 3$ original diet + $1 / 3$ experimental diet for 3 days; and then were fed with the whole experimental diet to start the feeding experiment. No vaccinations were given throughout the experimental period, and 3 birds in total died (mortality rate: $1.86 \%$ ).

Table 1 Composition and nutritive level ${ }^{1}$ of experimental diet ( $\%$ unless otherwise stated)

\begin{tabular}{|c|c|c|c|c|}
\hline \multirow{2}{*}{ Composition } & \multicolumn{4}{|c|}{ n-6:n-3 PUFA ratios } \\
\hline & $\mathrm{A}(12: 1)$ & $\mathrm{B}(9: 1)$ & $\mathrm{C}(6: 1)$ & $\mathrm{D}(3: 1)$ \\
\hline Maize & 66.20 & 66.20 & 66.20 & 66.20 \\
\hline Soyabean meal & 17.30 & 17.30 & 17.30 & 17.30 \\
\hline Lucerne powder & 10.70 & 10.70 & 10.70 & 10.70 \\
\hline Peanut oil & 1.30 & 1.28 & 1.16 & 1.06 \\
\hline Sunflower seed oil & 0.16 & 0.15 & 0.16 & 0.08 \\
\hline Linseed oil & 0.10 & 0.13 & 0.19 & 0.32 \\
\hline Palmitic acid & 0.37 & 0.37 & 0.38 & 0.40 \\
\hline Oleic acid & 0.07 & 0.07 & 0.11 & 0.14 \\
\hline Calcium hydrogen phosphate & 1.20 & 1.20 & 1.20 & 1.20 \\
\hline Stone powder ${ }^{2}$ & 0.60 & 0.60 & 0.60 & 0.60 \\
\hline L-Lysine hydrochloride & 0.35 & 0.35 & 0.35 & 0.35 \\
\hline DL-Methionine & 0.15 & 0.15 & 0.15 & 0.15 \\
\hline Sodium chloride & 0.50 & 0.50 & 0.50 & 0.50 \\
\hline Premix $^{3}$ & 1.00 & 1.00 & 1.00 & 1.00 \\
\hline Metabolizable energy, $\mathrm{ME}, \mathrm{MJ} / \mathrm{kg}^{4}$ & 11.70 & 11.70 & 11.70 & 11.70 \\
\hline Crude protein & 14.04 & 14.41 & 14.35 & 14.22 \\
\hline$n-6$ PUFA $^{5}$ & 0.60 & 0.60 & 0.56 & 0.50 \\
\hline$n-3$ PUFA $^{5}$ & 0.05 & 0.07 & 0.09 & 0.16 \\
\hline n-6:n-3 PUFA ratio & $12.00: 1$ & $8.57: 1$ & $6.22: 1$ & $3.12: 1$ \\
\hline
\end{tabular}

${ }^{1}$ values are expressed on a DM basis; ${ }^{2}$ a special feed material to supply calcium in China; ${ }^{3}$ provided per kg of premix; IU: vit. A 9.000; vit. D 1 400; vit. E 15; mg: vit. K 1.5; thiamin 2.2; riboflavin 3.8; vit. $\mathrm{B}_{12} 12$; pantothenic acid 12; nicotinic 75; choline 1 400; folic acid 0.5; Mg 600; Fe 96; $\mathrm{Mn}$ 66; Se 0.1 ; and Zn 60; ${ }^{4}$ metabolizable energy are calculated values; ${ }^{5}$ the content of $n-6$ (n-3) PUFA presented are the total, including linoleic acid (linolenic acid) and other kinds of n-6 (n-3) fatty acids such as arachidonic acid (AA, 20:4 n-6), etc

The $\mathrm{N}$ content of feed was determined by the Kjeldahl process (method number $948 \cdot 13$; AOAC, 1990). Fatty acids were analysed by gas chromatography (SHIMADZU GC-14B gas chromatograph, Shimadzu Corp. Kyoto, Japan) with 
methyl esterification by $10 \%$ sulphuric acid in methanol $\left(\mathrm{H}_{2} \mathrm{SO}_{4}-\mathrm{CH}_{3} \mathrm{OH}\right)$. The gas chromatography (GC) analyses were performed using a fused silica capillary column (DB-FFAP), $30 \mathrm{~m} \times 0.25 \mathrm{~mm}$ inner diameter (ID) $\times 0.25 \mu \mathrm{m}$ film thickness (J\&W Scientific, Agilent Technologies), a split/splitless injector, an automatic sampler (model AOC-17), and flame ionization detection in a SHIMADZU GC14B gas chromatograph (Shimadzu Corp. Kyoto, Japan). The initial temperature programme was: $130^{\circ} \mathrm{C}$ with a $1 \mathrm{~min}$ hold; ramp: $4^{\circ} \mathrm{C} / \mathrm{min}$ to $178^{\circ} \mathrm{C}, 1^{\circ} \mathrm{C} / \mathrm{min}$ to $225^{\circ} \mathrm{C}$, and then $40^{\circ} \mathrm{C} / \mathrm{min}$ to $245^{\circ} \mathrm{C}$, with a $13 \mathrm{~min}$ hold. The carrier gas was $\mathrm{H}_{2}$, with a linear velocity of $60 \mathrm{~cm} / \mathrm{s}$; a constant pressure of $102.4 \mathrm{kPa}$ was used. Fatty acid analysis was performed by autoinjection of $1 \mu \mathrm{l}$ of each sample at a split ratio of 7.5:1. The FID temperature was $250^{\circ} \mathrm{C}$, with air and nitrogen make-up gas flow rates of 450 and $10 \mathrm{ml} / \mathrm{min}$.

\section{Sampling design and sample handling}

Eight birds of each group were selected randomly, slaughtered quickly after a 24-h fast, on d 42, d 56 and d 70. Isolated livers were placed in an ice tray and index measurements were conducted as soon as possible. Liver tissues were mixed with $0.85 \%(\mathrm{w} / \mathrm{v})$ saline solution at a proportion of $1: 10$. The homogenates were centrifuged at $9000 \mathrm{~g}$ for $10 \mathrm{~min}$, and the supernatant fluid was collected for index testing.

\section{Index determination and test methods}

Assay kits for total superoxide dismutase (T-SOD) activity, glutathione peroxidase (GSH-Px) activity, catalase (CAT) activity, malondialdehyde (MDA), hydrogen peroxide $\left(\mathrm{H}_{2} \mathrm{O}_{2}\right)$, nitric oxide (NO), and tissue protein content (Prot.) were purchased from Jiancheng Com. Nanjing (China).

Tissue Prot. - the homogenate was centrifuged at $12.000 \mathrm{~g}$ for $10 \mathrm{~min}$ at $4^{\circ} \mathrm{C}$, and the supernatant was diluted to make a $1 \%$ solution with normal saline. A Coomassie brilliant blue protein kit was used to determine protein content.

T-SOD - A colorimetric method was used to determine T-SOD activity. One unit of SOD was defined as the enzyme activity causing 50\% inhibition in the nitroblue tetrazolium (NBT) reduction rate maintained at $37^{\circ} \mathrm{C}$. SOD activity was expressed as $\mathrm{U} / \mathrm{mg}$ tissue protein. The determination was conducted according to the manufacturer's instructions.

GSH-Px - 5,5-double thio-nitrobenzoic acid (DTNB colour method) was used to examine GSH-Px activity. One unit of GSHPx activity was defined as the amount of enzyme required to decrease the glutathione (GSH) concentration of $1 \mu \mathrm{mol} / \mathrm{l}$, per min per $\mathrm{mg}$ of tissue protein at $37^{\circ} \mathrm{C}$. The activity of GSH-Px was 
expressed as $\mathrm{U} / \mathrm{mg}$ tissue protein. The determination was performed according to the kit instructions.

CAT - A catalase ELISA kit was used in which the colour change was measured spectrophotometrically at a wavelength of $450 \pm 2 \mathrm{~nm}$. The concentration of CAT in the samples was then determined by comparing the optical density (O.D.) of the samples to the standard curve. The determination was performed according to the kit instructions.

NO - NO was assayed using the Griess method described by Saha et al. (2004). A standard curve of NO was determined by adding PBS with different concentrations of sodium nitrite solution to 40 to $160 \mu \mathrm{l}$ of Griess reagent, the solution was mixed and after $20 \mathrm{~min}$ the O.D. of the solution was measured spectrophotometrically at a wavelength of $550 \pm 2 \mathrm{~nm}$. Samples of $40 \mu 1$ were taken and the NO content $(\mu \mathrm{mol} / \mathrm{ml})$ in the sample was calculated according to the O.D. of the samples and the NO standard curve.

MDA, $\mathrm{H}_{2} \mathrm{O}_{2}$ - MDA was detected by the thiobarbituric acid (TBA) method; $\mathrm{H}_{2} \mathrm{O}_{2}$ was examined by coloration method; the determinations were performed according to the kit instructions.

\section{Statistical analysis}

Experimental data were processed using Microsoft Excel 2003 (Microsoft Corp. Redmond, WA), and the results are presented as means. Statistical analysis was carried out by ANOVA with the posthoc multiple comparison test of Tukey using SPSS software (SPSS Inc., Chicago, IL). P-values of $<0.05$ were considered statistically significant.

\section{RESULTS}

Effects of n-6:n-3 PUFA ratios on T-SOD, GSH-Px, and CAT in liver

The results presented in Table 2 showed that with increasing age, the level of liver T-SOD in each group declined to a minimum on $\mathrm{d} 70$, and the differences between ages were significant $(\mathrm{P}<0.05)$. Comparison of treatments showed that in general, T-SOD increased as n-6:n-3 PUFA ratios decreased, and there were significant differences between groups $(\mathrm{P}<0.05)$. In the $3: 1$ group it was significantly higher than the remaining groups $(\mathrm{P}<0.05)$, in the 6:1 group it was significantly higher than groups 9:1 and 12:1 $(\mathrm{P}<0.05)$, however, the difference was not significant between groups 9:1 and 12:1 ( $\mathrm{P}>0.05)$.

GSH-Px levels had a tendency to decline with age (Table 2). In group 12:1 in particular, a significant difference was found between ages $(\mathrm{P}<0.05)$, 
Table 2. Effects of n-6:n-3 PUFA ratios on liver total superoxide dismutase (T-SOD), glutathione peroxidase (GSH-Px), and catalase (CAT) in liver

\begin{tabular}{|c|c|c|c|c|c|c|c|c|}
\hline Enzymes & Age (d) & $\mathrm{A}(12: 1)$ & $\mathrm{B}(9: 1)$ & $\mathrm{C}(6: 1)$ & $\mathrm{D}(3: 1)$ & Mean & F-value & P-value \\
\hline \multirow{10}{*}{$\begin{array}{l}\text { T-SOD } \\
\text { U/mg }\end{array}$} & & $53.51^{\mathrm{a}, \mathrm{C}}$ & $56.80^{\mathrm{a}, \mathrm{C}}$ & $67.94^{\mathrm{a}, \mathrm{B}}$ & $74.08^{\mathrm{a}, \mathrm{A}}$ & 63.24 & 60.681 & 0.000 \\
\hline & 42 & $\mathrm{n}=7$ & $\mathrm{n}=8$ & $\mathrm{n}=7$ & $\mathrm{n}=8$ & $\mathrm{n}=30$ & & \\
\hline & & $41.03^{\mathrm{b}, \mathrm{C}}$ & $44.09^{\mathrm{b}, \mathrm{C}}$ & $60.05^{\mathrm{b}, \mathrm{B}}$ & $66.00^{\mathrm{b}, \mathrm{A}}$ & 53.07 & 91.810 & 0.000 \\
\hline & 56 & $\mathrm{n}=8$ & $\mathrm{n}=7$ & $\mathrm{n}=8$ & $\mathrm{n}=8$ & $\mathrm{n}=31$ & & \\
\hline & & $40.08^{\mathrm{b}, \mathrm{C}}$ & $39.03^{\mathrm{c}, \mathrm{C}}$ & $53.83^{\mathrm{c}, \mathrm{B}}$ & $66.00^{\mathrm{b}, \mathrm{A}}$ & 49.73 & 156.998 & 0.000 \\
\hline & 70 & $\mathrm{n}=8$ & $\mathrm{n}=8$ & $\mathrm{~N}=8$ & $\mathrm{n}=8$ & $\mathrm{n}=32$ & & \\
\hline & Mean & 44.50 & 46.60 & 60.20 & 68.69 & & & \\
\hline & & $n=23$ & $n=23$ & $n=23$ & $n=24$ & & & \\
\hline & F-value & 45.584 & 80.335 & 22.519 & 12.753 & & & \\
\hline & P-value & 0.000 & 0.000 & 0.000 & 0.000 & & & \\
\hline \multirow{10}{*}{$\begin{array}{l}\text { GSH-Px } \\
\text { U/mg }\end{array}$} & & $20.34^{\mathrm{a}, \mathrm{B}}$ & $18.23^{\mathrm{a}, \mathrm{B}}$ & $27.09^{\mathrm{a}, \mathrm{A}}$ & $29.01^{\mathrm{a}, \mathrm{A}}$ & 23.66 & 87.477 & 0.000 \\
\hline & 42 & $\mathrm{n}=7$ & $\mathrm{n}=8$ & $\mathrm{n}=7$ & $\mathrm{n}=8$ & $\mathrm{n}=30$ & & \\
\hline & & $16.16^{\mathrm{b}, \mathrm{B}}$ & $15.97^{\mathrm{b}, \mathrm{B}}$ & $23.00^{\mathrm{ab}, \mathrm{A}}$ & $24.99^{\mathrm{b}, \mathrm{A}}$ & 20.16 & 89.499 & 0.000 \\
\hline & 56 & $\mathrm{n}=8$ & $\mathrm{n}=7$ & $\mathrm{n}=8$ & $\mathrm{n}=8$ & $\mathrm{n}=31$ & & \\
\hline & & $14.10^{\mathrm{c}, \mathrm{C}}$ & $15.04^{\mathrm{b}, \mathrm{C}}$ & $20.00^{\mathrm{b}, \mathrm{B}}$ & $24.01^{\mathrm{b}, \mathrm{A}}$ & 18.29 & 90.837 & 0.000 \\
\hline & 70 & $\mathrm{n}=8$ & $\mathrm{n}=8$ & $\mathrm{n}=8$ & $\mathrm{n}=8$ & $\mathrm{n}=32$ & & \\
\hline & Mean & 16.72 & 16.38 & 22.97 & 26.00 & & & \\
\hline & & $\mathrm{n}=23$ & $\mathrm{n}=23$ & $\mathrm{n}=23$ & $\mathrm{n}=24$ & & & \\
\hline & F-value & 90.935 & 18.818 & 10.674 & 17.832 & & & \\
\hline & P-value & 0.000 & 0.000 & 0.001 & 0.000 & & & \\
\hline \multirow{10}{*}{$\begin{array}{l}\text { CAT } \\
\mathrm{U} / \mathrm{mg}\end{array}$} & & $5.67^{\mathrm{a}, \mathrm{B}}$ & $5.91^{\mathrm{a}, \mathrm{B}}$ & $6.06^{\mathrm{a}, \mathrm{B}}$ & $6.93^{\mathrm{a}, \mathrm{A}}$ & 6.16 & 10.676 & 0.000 \\
\hline & 42 & $\mathrm{n}=7$ & $\mathrm{n}=8$ & $\mathrm{n}=7$ & $n=8$ & $\mathrm{n}=30$ & & \\
\hline & & $5.43^{\mathrm{a}, \mathrm{A}}$ & $5.90^{\mathrm{b}, \mathrm{A}}$ & $5.90^{\mathrm{b}, \mathrm{A}}$ & $6.11^{\mathrm{b}, \mathrm{A}}$ & 5.83 & 2.055 & 0.130 \\
\hline & 56 & $n=8$ & $n=7$ & $n=8$ & $n=8$ & $n=31$ & & \\
\hline & & $4.54^{\mathrm{b}, \mathrm{B}}$ & $4.45^{\mathrm{b}, \mathrm{B}}$ & $4.76^{\mathrm{b}, \mathrm{B}}$ & $5.86^{\mathrm{b}, \mathrm{A}}$ & 4.91 & 0.217 & 0.000 \\
\hline & 70 & $n=8$ & $n=8$ & $\mathrm{n}=8$ & $\mathrm{n}=8$ & $n=32$ & & \\
\hline & Mean & 5.19 & 5.34 & 5.58 & 6.30 & & & \\
\hline & & $\mathrm{n}=23$ & $\mathrm{n}=23$ & $\mathrm{n}=23$ & $\mathrm{n}=24$ & & & \\
\hline & F-value & 11.521 & 19.025 & 16.872 & 10.618 & & & \\
\hline & P-value & 0.000 & 0.000 & 0.000 & 0.001 & & & \\
\hline
\end{tabular}

but no significant differences were detected between d 56 and d 70 in the three other groups $(\mathrm{P}>0.05)$. Among treatments, GSH-Px increased as the n-6:n-3 PUFA ratios decreased. On d 42 and d 56, GSH-Px was higher in the 3:1 and 6:1 groups, and significantly higher than in groups 9:1 and 12:1 $(\mathrm{P}<0.05)$, however, the differences between groups $3: 1$ and $6: 1(\mathrm{P}>0.05), 9: 1$, and 12:1 $(\mathrm{P}>0.05)$ were not significant; on $\mathrm{d} 70$, the $3: 1$ group was significantly higher than the three other groups $(\mathrm{P}<0.05)$.

Overall, the levels of liver CAT also declined with increasing age (Table 2). CAT on d 42 in each group was significantly higher than on $d 70$ 
$(\mathrm{P}<0.05)$. Comparison among treatments showed that on $\mathrm{d} 42$ and $\mathrm{d} 70$, CAT in 3:1 was significantly higher than in the three other groups $(\mathrm{P}<0.05)$, while differences among the other three groups were not significant $(\mathrm{P}>0.05)$; at $\mathrm{d} 56$, there was no difference in CAT among treatments $(\mathrm{P}>0.05)$.

Effects of n-6:n-3 PUFA ratios on $\mathrm{MDA}, \mathrm{H}_{2} \mathrm{O}_{2}$, and $\mathrm{NO}$ in liver

Table 3 showed that MDA increased with age and was distinctly higher on $\mathrm{d} 7$. In the 12:1 group, significant differences existed in MDA between ages $(\mathrm{P}<0.05)$, while the differences were not significant between $\mathrm{d} 56$ and $\mathrm{d} 70(\mathrm{P}>0.05)$ in groups 9:1 and 6:1. MDA levels decreased as the n-6:n-3 PUFA ratios decreased

Table 3. Effects of n-6:n-3 PUFA ratios on liver malondialdehyde (MDA), hydrogen peroxide $\left(\mathrm{H}_{2} \mathrm{O}_{2}\right)$, and nitric oxide $(\mathrm{NO})$ in liver

\begin{tabular}{|c|c|c|c|c|c|c|c|c|}
\hline Substances & Days & $\mathrm{A}(12: 1)$ & $\mathrm{B}(9: 1)$ & $\mathrm{C}(6: 1)$ & $\mathrm{D}(3: 1)$ & Mean & F-value & P-value \\
\hline \multirow{10}{*}{$\begin{array}{l}\text { MDA } \\
\mathrm{nmol} / \mathrm{mg}\end{array}$} & & $2.46^{\mathrm{c}, \mathrm{A}}$ & $2.59^{\mathrm{b}, \mathrm{A}}$ & $1.90^{\mathrm{b}, \mathrm{B}}$ & $2.10^{\mathrm{b}, \mathrm{B}}$ & 2.27 & 24.644 & 0.000 \\
\hline & 42 & $\mathrm{n}=7$ & $\mathrm{n}=8$ & $\mathrm{n}=7$ & $\mathrm{n}=8$ & $\mathrm{n}=30$ & \multirow{3}{*}{204.506} & \multirow{3}{*}{0.000} \\
\hline & & $4.03^{\mathrm{b}, \mathrm{A}}$ & $3.90^{\mathrm{a}, \mathrm{A}}$ & $2.30^{\mathrm{a}, \mathrm{B}}$ & $2.10^{\mathrm{b}, \mathrm{B}}$ & 3.06 & & \\
\hline & 56 & $n=8$ & $\mathrm{n}=7$ & $\mathrm{n}=8$ & $\mathrm{n}=8$ & $n=31$ & & \\
\hline & & $4.31^{\mathrm{a}, \mathrm{A}}$ & $4.12^{\mathrm{a}, \mathrm{A}}$ & $2.34^{\mathrm{a}, \mathrm{B}}$ & $2.35^{\mathrm{a}, \mathrm{B}}$ & 3.29 & \multirow[t]{6}{*}{222.119} & \multirow[t]{6}{*}{0.000} \\
\hline & 70 & $\mathrm{n}=8$ & $\mathrm{n}=8$ & $\mathrm{n}=8$ & $\mathrm{n}=8$ & $n=32$ & & \\
\hline & Mean & 3.65 & 3.55 & 2.23 & 2.18 & & & \\
\hline & & $\mathrm{n}=23$ & $\mathrm{n}=23$ & $n=23$ & $\mathrm{n}=24$ & & & \\
\hline & F-value & 173.961 & 100.052 & 10.886 & 5.390 & & & \\
\hline & P-value & 0.000 & 0.000 & 0.001 & 0.013 & & & \\
\hline \multirow{9}{*}{$\begin{array}{l}\mathrm{H}_{2} \mathrm{O}_{2} \\
\mu \mathrm{mol} / \mathrm{mg}\end{array}$} & \multirow{2}{*}{42} & $\begin{array}{l}1.21^{\mathrm{c}, \mathrm{A}} \\
\mathrm{n}=7\end{array}$ & $\begin{array}{l}1.24^{\mathrm{c}, \mathrm{A}} \\
\mathrm{n}=8\end{array}$ & $\begin{array}{l}0.86^{\mathrm{b}, \mathrm{B}} \\
\mathrm{n}=7\end{array}$ & $\begin{array}{l}0.91^{\mathrm{b}, \mathrm{B}} \\
\mathrm{n}=8\end{array}$ & $\begin{array}{l}1.06 \\
n=30\end{array}$ & 20.446 & 0.000 \\
\hline & & $1.72^{\mathrm{b}, \mathrm{A}}$ & $1.64^{\mathrm{b}, \mathrm{A}}$ & $1.51^{\mathrm{a}, \mathrm{A}, \mathrm{B}}$ & $1.32^{\mathrm{a}, \mathrm{B}}$ & 1.55 & \multirow[t]{2}{*}{8.337} & \multirow[t]{2}{*}{0.000} \\
\hline & \multirow[t]{2}{*}{56} & $\mathrm{n}=8$ & $\mathrm{n}=7$ & $n=8$ & $\mathrm{n}=8$ & $n=31$ & & \\
\hline & & $2.24^{\mathrm{a}, \mathrm{A}}$ & $1.96^{\mathrm{a}, \mathrm{B}}$ & $1.43^{\mathrm{a}, \mathrm{C}}$ & $1.36^{\mathrm{a}, \mathrm{C}}$ & 1.76 & \multirow[t]{6}{*}{44.283} & \multirow[t]{6}{*}{0.000} \\
\hline & 70 & $\mathrm{n}=8$ & $\mathrm{n}=8$ & $\mathrm{n}=8$ & $\mathrm{n}=8$ & $n=32$ & & \\
\hline & \multirow[t]{2}{*}{ Mean } & 1.75 & 1.63 & 1.28 & 1.20 & & & \\
\hline & & $\mathrm{n}=23$ & $\mathrm{n}=23: 1$ & $\mathrm{n}=23$ & $\mathrm{n}=24$ & & & \\
\hline & F-value & 55.745 & 42.765 & 57.719 & 32.477 & & & \\
\hline & P-value & 0.000 & 0.000 & 0.000 & 0.000 & & & \\
\hline \multirow{10}{*}{$\begin{array}{l}\mathrm{NO} \\
\mu \mathrm{mol} / \mathrm{mg}\end{array}$} & \multirow[b]{2}{*}{42} & $7.82^{\mathrm{b}, \mathrm{A}}$ & $7.33^{\mathrm{a}, \mathrm{A}}$ & $6.60^{\mathrm{a}, \mathrm{B}}$ & $6.30^{\mathrm{a}, \mathrm{B}}$ & 7.00 & \multirow[t]{2}{*}{27.049} & \multirow[t]{2}{*}{0.000} \\
\hline & & $\mathrm{n}=7$ & $\mathrm{n}=8$ & $\mathrm{n}=7$ & $\mathrm{n}=8$ & $\mathrm{n}=30$ & & \\
\hline & \multirow{3}{*}{56} & $8.91^{\mathrm{a}, \mathrm{A}}$ & $7.50^{\mathrm{a}, \mathrm{B}}$ & $6.90^{\mathrm{a}, \mathrm{B}}$ & $6.49^{\mathrm{a}, \mathrm{B}}$ & 7.45 & \multirow[t]{2}{*}{42.586} & \multirow[t]{2}{*}{0.000} \\
\hline & & $\mathrm{n}=8$ & $\mathrm{n}=7$ & $\mathrm{n}=8$ & $\mathrm{n}=8$ & $\mathrm{n}=31$ & & \\
\hline & & $9.40^{\mathrm{a}, \mathrm{A}}$ & $7.90^{\mathrm{a}, \mathrm{B}}$ & $7.01^{\mathrm{a}, \mathrm{C}}$ & $6.55^{\mathrm{a}, \mathrm{C}}$ & 7.71 & \multirow[t]{6}{*}{81.921} & \multirow[t]{6}{*}{0.000} \\
\hline & 70 & $\mathrm{n}=8$ & $\mathrm{n}=8$ & $\mathrm{n}=8$ & $\mathrm{n}=8$ & $n=32$ & & \\
\hline & \multirow[t]{2}{*}{ Mean } & 8.75 & 7.66 & 6.85 & 6.45 & & & \\
\hline & & $\mathrm{n}=23$ & $n=23$ & $n=23$ & $n=24$ & & & \\
\hline & F-value & 19.409 & 2.325 & 1.488 & 1.720 & & & \\
\hline & P-value & 0.000 & 0.122 & 0.249 & 0.203 & & & \\
\hline
\end{tabular}


in all analysed ages and were significantly lower in groups 3:1 and 6:1 than the other two groups $(\mathrm{P}<0.05)$, but the differences between 3:1 and 6:1 $(\mathrm{P}>0.05)$, and between 9:1 and 12:1 ( $\mathrm{P}>0.05)$ were not significant.

The results of $\mathrm{H}_{2} \mathrm{O}_{2}$ shown in Table 3 indicated that $\mathrm{H}_{2} \mathrm{O}_{2}$ levels increased when the geese aged, and significant differences were detected between sampling ages $(\mathrm{P}<0.05)$. It was further observed that $\mathrm{H}_{2} \mathrm{O}_{2}$ decreased as the $n-6: n-3$ PUFA ratios decreased and, moreover, 3:1 and 6:1 were significantly lower than in the other two groups at $\mathrm{d} 42(\mathrm{P}<0.05)$; in group 3:1 it was significantly lower than in groups $9: 1$ and $12: 1$ on $\mathrm{d} 56(\mathrm{P}<0.05)$; and when the geese were aged 70 days, in groups 3:1 and 6:1 $\mathrm{H}_{2} \mathrm{O}_{2}$ was significantly lower than in 9:1 $(\mathrm{P}<0.05)$, and in 9:1, it was significantly lower than 12:1 $(\mathrm{P}<0.05)$.

The NO level increased with age in each group (Table 3), with the rise in group 12:1 reaching significance $(\mathrm{P}<0.05)$, while in the other three groups the changes were not significant among ages $(\mathrm{P}>0.05)$. With the decrease of $n-6: n-3$ PUFA ratios, NO had a tendency to decrease in general. On d 42, in groups 3:1 and 6:1 it was significantly lower than in the other two groups $(\mathrm{P}<0.05)$; on d 56 and 70 , in group 12:1 NO was significantly higher than the other three groups $(\mathrm{P}<0.05)$.

\section{DISCUSSION}

Effects of n-6:n-3 PUFA ratios on T-SOD, GSH-Px, CAT in liver. The body always produces free radicals but, at the same time, has a free radical scavenging system, which protects cytosolic organelles from the damaging effects of the hydroperoxides formed by normal aerobic metabolism (Bertram and Hass, 2008). If the balance is destroyed, however, excessive free radicals might attack cell membranes as well as nucleic acids, proteins, and other biological macromolecules, leading eventually to damage of cell function. SOD is one of the most important enzymes that act as cellular antioxidants. It is present in the cytoplasm and mitochondria in order to maintain a low concentration of superoxide anions, which are the major oxygen radical. GSH-Px is another important peroxidase present in the body, and plays a key role in protecting the cell membrane. GSH-Px reduces the concentrations of $\mathrm{H}_{2} \mathrm{O}_{2}$ formed during respiration, and specifically catalyzes the glutathione reduction of lipid peroxides (Johnson et al., 2003; Lu, 2006). CAT is a kind of removal reagent, and can promote catalysis of $\mathrm{H}_{2} \mathrm{O}_{2}$ to $\mathrm{H}_{2} \mathrm{O}$ and $\mathrm{O}_{2}$, and consequently protects cells from $\mathrm{H}_{2} \mathrm{O}_{2}$ toxicities (Desagher et al., 1996). Therefore, SOD, GSH-Px, and CAT activity are important indicators reflecting the body's antioxidant capacity (Levin, 1988; Sun and Liu, 2009).

Research has shown that n-3 PUFA not only scavenges free radicals directly, but also improves the activity of antioxidant enzymes such as SOD, GSH-Px, thus effectively eliminates free radicals and lipid peroxides, improves the body's 
antioxidant and anti-aging capability (Liu, 2009). The current work showed that the activities of liver T-SOD, GSH-Px, and CAT decreased with age, and indicated that the ability to eliminate oxygen radicals, antioxidant capacity, and anti-aging properties tended to decline gradually with age. The activities of liver T-SOD, GSH-Px, and CAT increased as the n-6:n-3 PUFA ratios decreased. Among four groups, the $3: 1$ and $6: 1$ groups were significantly higher than the other two groups, and the $3: 1$ group was significantly higher than $6: 1$, confirming previous studies in which n-3 PUFA could increase antioxidant capacity. n-3 PUFA may improve the antioxidant enzyme activities by increasing the expression of their genes, and, in our opinion, this should be investigated promptly.

Effects of n-6:n-3 PUFA ratios on $M D A, \mathrm{H}_{2} \mathrm{O}_{2}$, and $\mathrm{NO}$ in the liver. The unsaturated fatty acids in lipids are easily damaged by oxidative free radicals and produce end-products of lipid peroxidation, specifically, MDA (Mayne, 2003; Cortinas et al., 2004). MDA causes cell toxicity, cross-linking proteins within and between molecules, leading to cell damage, releasing a large number of inflammatory mediators. MDA has a significant inhibitory effect on mitochondrial respiratory function, pyruvate dehydrogenase, $\alpha$-ketoglutarate dehydrogenase, etc. (Long et al., 2005). The toxicity of lipid hydroperoxides to animals has best been illustrated by the lethal phenotype of glutathione peroxidase 4 (GPX4) knockout mice. These animals did not survive past embryonic day 8 , indicating that the lipid hydroperoxidase was absolutely essential for life (Muller et al., 2007). Despite being a simple molecule, $\mathrm{NO}$ is a fundamental component in the fields of neuroscience, physiology, and immunology (Culotta and Koshland, 1992; Lander et al., 1993; Macphail et al., 2003). $\mathrm{NO}$ and $\mathrm{O}_{2}^{-1}$ play key roles in toxic oxidation, can inactivate enzymes, inhibit respiratory chain enzymes, destroy mitochondrial structure, and cause oxidative damage (Forsythe et al., 2002). Thus, $\mathrm{MDA}, \mathrm{H}_{2} \mathrm{O}_{2}$, and NO levels can reflect the body's lipid peroxidation and indirectly reflect the degree of cell membrane damage (Erden-Inal et al., 2001).

Studies have shown that $n-3$ series PUFA-rich oils have functions of removing lipid peroxides and protecting cells from the effects of oxygen free radical damage. The present work showed that MDA, $\mathrm{H}_{2} \mathrm{O}_{2}$, and $\mathrm{NO}$ increased with age. As is known, cells decrease oxidation resistance gradually when the body ages. In addition, $\mathrm{MDA}, \mathrm{H}_{2} \mathrm{O}_{2}$, and $\mathrm{NO}$ levels in the liver tended to decrease as n-6:n-3 PUFA ratios decreased. This might be attributed to the increase of antioxidant enzyme activities by n-3 PUFA, as described above. Among the treatments, the 3:1 and 6:1 group was significantly lower than the two other groups. This result demonstrated that low n-6:n-3 PUFA ratios in diets could increase the ability to remove lipid peroxides of liver cells, and thus improve the antioxidant and antiaging capacity. 


\section{CONCLUSIONS}

Based on the results of this study, it can be concluded that the antioxidant function of the liver was influenced by dietary n-6:n-3 PUFA ratios. Diets containing low $n-6: n-3$ PUFA ratios $(3: 1$ or $6: 1)$ could improve the activities of enzymes such as total superoxidase dismutase, glutatione peroxide, and catalase and decrease the level of substances such as hydrogen peroxide, malondialdehyde and nitric oxide in the liver. This is relevant to improving the antioxidant capability of Yangzhou goslings aged from 42 to 70 days. Future studies should be undertaken to clarify the range of this ratio.

\section{REFERENCES}

AOAC, 1990. Association of Official Analytical Chemists, Official Methods of Analysis. $15^{\text {th }}$ Edition. Virginia, USA

Bertram C., Hass R., 2008. Cellular responses to reactive oxygen species-induced DNA damage and aging. Biol. Chem. 389, 211-220

Cortinas L., Villaverde C., Galobart J., Baucells D., Codony R., Barroeta A.C., 2004. Fatty Acid content in chicken thigh and breast as affected by dietary polyunsaturation level. Poultry Sci. $83,1155-1164$

Crane J.Q., French K.R., Buller K.M., 2005. Patterns of neuronal activation in the rat brain and spinal cord in response to increasing durations of restraint stress. Stress 8, 199-211

Culotta E., Koshland Jr. D.E., 1992. NO news is good news. (nitric oxide; includes information about other significant advances \& discoveries of 1992) (Molecule of the Year). Science 258, 1862-1864

Desagher S., Glowinski J., Premont J., 1996. Astrocytes protect neurons from hydrogen peroxide toxicity. J. Neurosci. 16, 2553-2562

Eder K., Flader D., Hirche F., Brandsch C., 2002. Excess dietary vitamin e lowers the activities of antioxidative enzymes in erythrocytes of rats fed salmon oil. J. Nutr. 132, 3400-3404

Erden-Inal M., Kahraman A., Koken T., 2001. Beneficial effects of quercetin on oxidative stress induced by ultraviolet A. Clin. Exp. Dermatol. 26, 536-539

Forsythe R.M., Xu D.Z., Lu Q., 2002. Lipopolysaccharide-induced- enterocyte-derived nitric oxide induced intestinal monolayer permeability in an autocrine fashion. Shock Augusta Ga 17, 180184

Johnson R.J., Kang D.H., Feig D., 2003. Is There a pathogenetic role for uric acid in hypertension and cardiovascular and renal disease? Hypertension 41, 1183-1186

Lander H.M., Sehajpal P., Levine D.M., Novogrodsky A., 1993. Activation of human peripheral blood mononuclear cells by nitric oxide-generating compounds. J. Immunol. 150, 1509-1516

Levin A.A., 1988. The reversibility of nitrobenzene-induced testicular toxicity:continuous monitoring of sperm output from vasocystotomized rats. Toxicology 53, 219-230

Liu B.Y., Wang Z.Y., Yang H.M., Wang X.B., Hu P., Lu J., 2010. Developmental morphology of the small intestine in Yangzhou goslings. Afr. J. Biotechnol. 9, 7392-7400

Liu L.C., 2009. Effect of unsaturated fatty acid and monensin on rumen and blood fatty acid synthesis in sheep [D] (in Chinese). Ha Erbing, Northeast Agricultural University 
Long J.G., Wang X.M., Gao H.X., Liu C.S., Liu Z., Miao M.Y., Liu J.K., 2005. Malonaldehyde inhibits respiratory function and enzyme activities in isolated rat liver mitochondria (in Chinese). Acad. J. Second Military Med. Univ. 26, 1131-1135

Lu C.W., 2006. Studies on toxicology of nitrobenzene on rats [D] (in Chinese). HaErbing, Northeast Agr. Univ., pp. 23-33

Macphail S.E., Gibney C.A., Brooks B.M., Booth C.G., Flanagan B.F., Coleman J.W., 2003. Nitric oxide regulation of human peripheral blood mononuclear cells: critical time dependence and selectivity for cytokine versus chemokine expression. J. Immunol. 171, 4809-4815

Mayne S.T., 2003. Antioxidant nutrients and chronic disease: use of biomarkers of exposure and oxidative stress status in epidemiologic research. J. Nutr. 133, 933-940

Muller F.L., Lustgarten M.S., Jang Y., Richardson A., Van Remmen H., 2007. Trends in oxidative aging theories. Free Radical Biol. Med. 43, 477-503

NRC, 1994. Nutrient Requirements of Poultry. $9^{\text {th }}$ revised Edition. National Academy Press. Washington, DC

Saha K., Lajis N.H., Israf D.A., 2004. Evaluation of antioxidant and nitric oxide inhibitory of selected malaysian medicinal plants. J. Ethnopharmacol. 92, 263-267

Shi S.R., Wang Z.Y., Yang H.M., Zhang Y.Y., 2007. Nitrogen requirement for maintence in Yangzhou goslings. Brit. Poultry Sci. 48, 205-209

Sun G., Liu D., 2009. Effect of nitrobenzene on antioxidation of immune organ in duck (in Chinese). Chinese Poultry 31, 23-26

Wang M., Wang D.P., Wang W.F., Hiroshi K., Han F.S., Yang X.X., He R.R., 2009. Protective effects of Baoligan capsule on liver lnjury induced by stress traditional Chinese drug (in Chinese). Res. Clin. Pharmacol. 20, 412-415

Wang Z.Y., Shi S.R., Shi Y.J., Zhang J., Zhou Q.Y., 2008. A Comparison of methods to determine amino acid availability of feedstuffs in cecectomized ganders. Poultry Sci. 87, 96-100

Wang Z.Y., Shi S.R., Zhou Q.Y., Yang H.M., Zou J.M., Zhang K.N., Han H.M., 2010. Response of growing goslings to dietary methionine from 28 to 70 days of age. Brit. Poultry Sci. 51, 118121 